EPRA International Journal of Economic and Business Review-Peer Reviewed Journal

Volume - 9, Issue -3, March 2021 | e-ISSN: 2347 - 9671| p- ISSN: 2349 - 0187

\title{
PERFORMANCE OF MAHATMA GANDHI NATIONAL RURAL EMPLOYMENT GUARANTEE SCHEME IN KARNATAKA: A SEASONAL WISE ANALYSIS
}

\begin{tabular}{|c|c|}
\hline Odegouda R T & $\begin{array}{c}\text { 'Research Scholar, Department of Economics, } \\
\text { Karnatak University, Dharwad }\end{array}$ \\
\hline Dr. S. B. Nari ${ }^{2}$ & $\begin{array}{c}{ }^{2} \text { Associate Professor, Department of Economics, } \\
\text { Karnatak University, Dharwad. }\end{array}$ \\
\hline
\end{tabular}

Rural labours are migrating to the urban areas searching for jobs, because of they don't get jobs in agricultural lean season and Most of the unorganised sector workers are deprived of basic social security measures, like, health, income, employment etc. In this context, the Mahatma Gandhi National Rural Employment Guarantee Scheme (MGNREGA) as a fall-back employment source is designed to make significant difference to livelihood security in rural areas especially rural poor. The study mainly focused on four questions like, does MGNREGS has properly used fund by seasonal wise; to know the seasonal wise household demanded and provided for employment; to know the share of employment generation among social groups and dose MGNREGS has created more persondays in drought affected years in Karnataka. In this context the present study an attempt to the Seasonal Variation of Employment Generation and Utilization of Fund under MGNREGS in Karnataka. The study found that Whereas coefficient of variation is less in summer season it is evidently on an average 83 percent of workers are benefited from employment during the summer and Rabi season. As compared to the all financial years, on an average of women generated Persondays was highest 44.50 percent in summer season followed by 43.64 percent in Rabi, but in Kharif season was least 11.85 percent. Similar in all year's during summer and Rabi season have highest proportion of hundred days work done, but least proportion in Kharif season. The study mainly efforts on rainy season it means south west monsoon period the proportion of average rainfall was highest $(486 \mathrm{~mm}$ in July 2013), but it is continuously declined to 244mm in July 2017. But not much rainfall in other remaining months. The study suggests that the MGNREGS programme works should be season wise planning and timely work distribution for who have demanded for work and also to concentrate on more agriculture related works and awareness in gross root level.
\end{abstract}

KEYWORDS: MGNREGS, Seasonal wise Employment Generation, Fund Utilization, Average Rainfall and Drought.

\section{INTRODUCTION}

Unemployment, inequality and poverty these are the main problems of the developing

country like India. Half of peoples are predominantly depending on agriculture activities in India. Now 
days agriculture growth rate is declining. Rural labours are migrating to the urban areas searching for jobs, because of they don't get jobs in agricultural lean season. According to the latest estimates of Planning Commission (2011-12), around 21 per cent of total population is living below poverty line. On the other side, 25 percent of rural people are poor. The rate reduction in poverty especially in rural areas of Karnataka in 2011-12 compared to 2009-10 figures is quite low against the all India rate. Further, the higher rate of unemployment in CDS measure (2009-10) indicates prevalence of high seasonal employment in both rural Karnataka and rural India. India in general and Karnataka in particular, the number of workers in unorganised sector is overwhelmingly high and so also their preponderance across all occupations and activities. Most of the unorganised sector workers are deprived of basic social security measures, like, health, income, employment etc. In this context, the Mahatma Gandhi National Rural Employment Guarantee Act (MGNREGA) as a fall-back employment source is designed to make significant difference to livelihood security in rural areas especially rural poor (Prasanna, 2014).

The National Rural Employment Guarantee Act, (NREGA) was notified on Sept seven, 2005. The Act was notified in two hundred districts within the 1st section with impact from February 2, 2006 so extended to an extra one hundred thirty districts within the yr 2007-2008. The remaining districts

\section{REVIEW OF LITRATURE}

Murthy and Indumati (2011) in this study have used the macro level data on performance of MGNREGA in drought prone states of Karnataka and Rajasthan as well as irrigation dominated state of Andhra Pradesh. this study has unconcealed that the impact of MGNREGA wage on the economic insufficiency of labour is comparatively modest when put next with the impact of hike in non-farm wages. Even though the availability of food security through public distribution system has contributed to the economic insufficiency of labour, the relative hike in non-farm wages is contributing to higher economic insufficiency of labour instead of PDS and MGNREGA wages. The study has suggested subsidies for farm mechanization should be provided in order to sustain food and livelihood security in the drought prone as well as irrigation-dominant states of India A study conducted in Karnataka in 2010-11 by Pani and Iyer (2011), shows that the multiplier effects of expenditure from MGNREGA are quite significant, ranging from 3.1 in the north-west region to 3.6 in the Malnad and coastal districts of the State. The effect of the multiplier on the rural economy would be influenced by how much of the additional purchasing power generated from a rural employment scheme is spent on items produced in the rural economy. The study found that a greater proportion of the income, from 48 to 66 per cent for men and women, generated from MGNREGA tends to be were notified underneath the NREGA with result from April one, 2008. The first phase covered five districts in Karnataka: Bidar, Chitradurga, Davanagere, Kalaburagi and Raichur. The second phase extended the scheme to six more districts: Belagavi, Ballari, Chikkamagaluru, Hassan, Kodagu and Shivamogga. The rest of the state was covered in the third phase. The objective of the Act is to boost resource security in rural areas by providing a minimum of one hundred days of secure wage employment in a very year to each household whose adult members volunteer to try to unskilled manual work. It aims to form a robust social safety internet for the vulnerable teams by providing a retreat employment supply, when other employment alternatives are scarce or inadequate. Through the method of providing employment on works that address causes of chronic economic condition like drought, deforestation and soil erosion, the Act seeks to strengthen the natural resource base of rural resource and make sturdy assets in rural areas. It further seeks the empowerment of rural poor through the processes of a rights-based law and to provide a model of governance reform based on transparency and grassroots democracy. in this backdrop the present study an attempt an assessment of seasonal wise employment generation and fund utilization through MGNREGS in Karnataka.

spent on the rural economy. Vanitha and Murthy (2011) the study conducted on MGNREG programme in Mysore district during2009-10 the study found 47.8 percent of women workers are registered. the work status in sample villages has been 96.8 percent of natural resource management works and 74.2 percent of works are related to community works. These works are needed to be taken up on individual farmers, it is balancing the agriculture land. The MGNREGA programme has positive impact on beneficiary's socio and economic condition in the villages. The study has found that, there has been reduction within the worker of labour to agriculture to the extent of forty. 67 person-days p.a. on a mean when the implementation of MGNREGS. Hence, MGNREGS works have to be compelled to be dead solely throughout offseason. Sharma et. al (2016) the study to measure the economic impact of three major social protection programmes, namely, the Mahatma Gandhi National Rural Employment Guarantee Act, Indira Awaas Yojana, and the National social insurance Programme in 2011-12 employing a social accounting matrix. The study found it out that these programmes have important impacts on output across completely different sectors of the economy, on financial gain generation and distribution of various home categories in urban and rural areas, on 
employment across completely different sectors of

\section{OBJECTIVES OF THE STUDY}

1. To analyze the trends and patterns of seasonal wise fund utilization under MGNREGS in Karnataka.

2. To assess the impact of MGNREGS on seasonal wise employment generation in Karnataka.

\section{METHODOLOGY OF THE STUDY}

The present study is purely based on secondary data. The data has been taken from the 2008-09 to 2016-17. The secondary data sources are collected from online website www.mgnrega.nic.in and Rural Development and Panchayat Raj (RDPR). The simple tools used such as Percentage, Average and Coefficient of variation for the analyses. To know the insight of the MGNREGA Programme. In this backdrop, the data are classified into three type seasonal like Kharif, Rabi and Summer. The study mainly focused on three questions like, does

\section{RESULT AND DISCUSSION}

5.1 To Analyze the Trends and Patterns of Seasonal Wise Fund Utilization under MGNREGS in Karnataka.

The act has completed thirteen years successfully. It is become a world largest public work programme. It gives an employment opportunity for who have social excluded in the society. Intended to the financial performance of MGNREGA in Karnataka.

The below figure no.1 shows that trends and pattern of fund allocation and utilization of fund under MGNREGS in Karnataka during the period 2006-07 to 2018-19. The fund utilization under MGNREGA has been increased from 66.35 percent in 2006-07 (for five districts) to 97.75 percent in the economy, and even on income generation.

3. To examine the comparison between drought, average rainfall and person days generated under MGNREGS in Karnataka.

4. To suggest policy implication for MGNREG programme in Karnataka.

MGNREGS properly used fund by seasonal wise; to know the seasonal wise household demanded and provided for employment; to know the share of employment generation among social groups and share of women and lastly, is there any changes in persondays generated because of low rain fall or drought. In this context the present study an attempt to the Seasonal Variation of Employment Generation and Utilization of Fund under MGNREGS in Karnataka.

2018-19 for (30 districts). It has been increasing until 2009-10 about 72.95 percent than decreased to 62.93 percent in 2010-11. Both availability of fund and expenditure increasing continuously since 2006-07 to 2018-19, but decreased in 2012-13. It was evident that there has been proper utilization of fund was found in 2018-19 with 97.75 percent in Karnataka. But worst performance in utilizing the fund has seen in 2010-11 which was accounted for 62.93 percent even though the availability of fund was higher. The amount of expenditure incurred is highest in the year 2018-19, but the percentage of fund utilized is highest over these thirteen years.

Figure No.1 Trends and Pattern of Fund Utilization under MGNREGS in Karnataka (2008-09 to 2018-19)

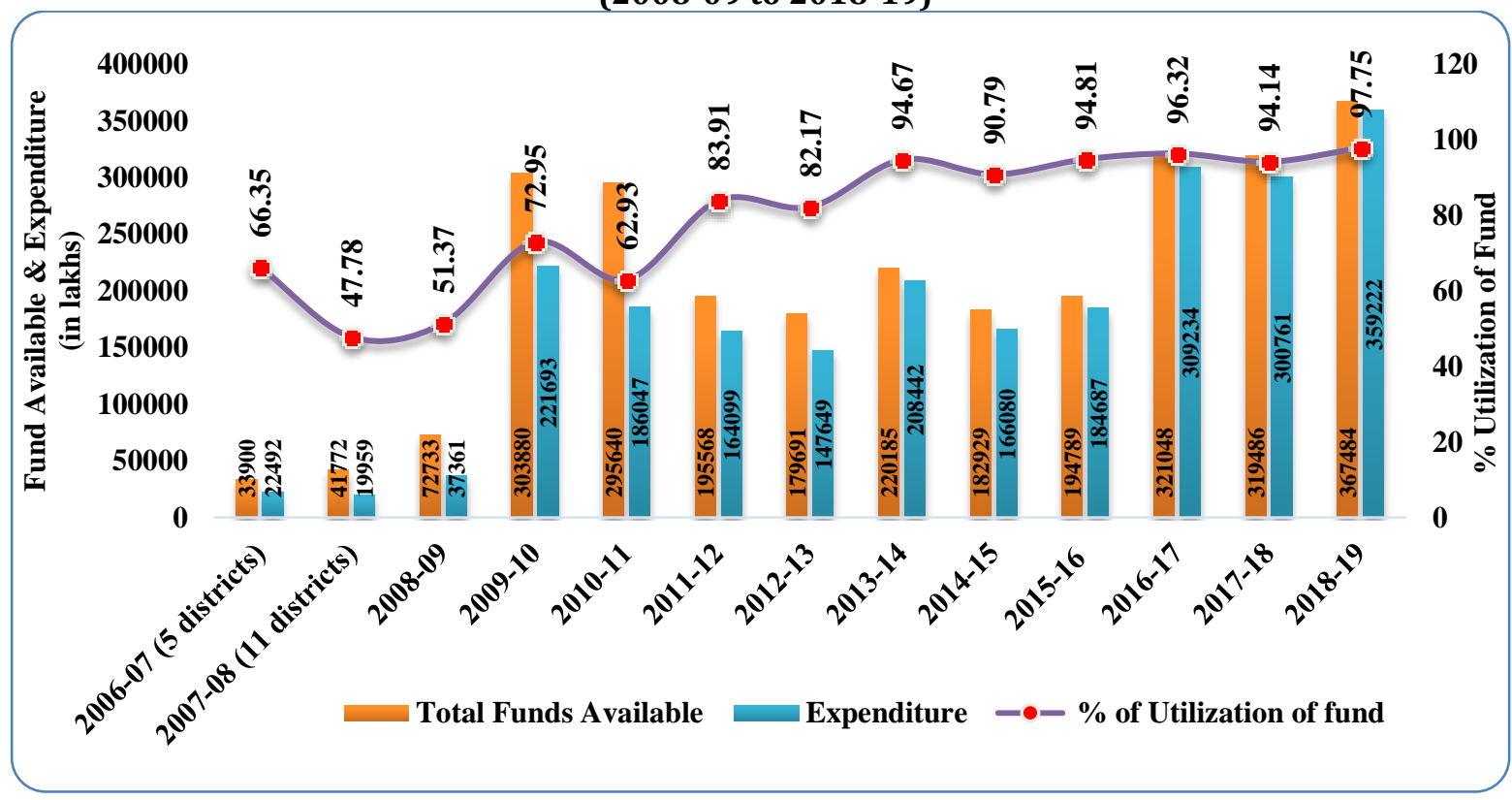

Source: www.mgnrega.nic.in 


\subsubsection{The Seasonal Wise Fund Utilization under MGNREGS in Karnataka (2008-16)}

The percentage of fund utilization against total available fund and percentage of expenditure on wage against total expenditure under MGNREGS in Karnataka during the period 2008-09 to 2015-16. The below figure no.2 illustrated that the seasonal wise percentage of fund utilization and percentage of expenditure on wage. In the year 2008-09 more than 37.07 percent of the fund utilization was highest in during Rabi season. Followed by kharif (19.26) and summer (20.21) seasons are less percent of the fund utilization. As compared to the year 2015-16 more than 155.79 percent during Summer and 123.31 percent in Rabi season was highest fund utilization followed by Kharif season (58.8) not as much of percent of fund utilization. Overall years the fund utilization has been significantly increased during
Rabi and Summer season in the period 2008-09 to 2015-16. But in the year 2014-15 the Kharif season was highest (163.97) percent of fund utilization. The expenditure on 60:40 wages to material ratio has to be maintained in the year 2008-09 the wage expenditure was highest (72.16) percent during Summer season, as followed by Kharif and Rabi Season was maintained 60 percent ratio. As compared to the in the year 2015-16 the wage expenditure was maintained $60 \%$ ratio during the summer and Rabi season. But the Kharif season has not maintained 60 percent ratio of wage expenditure. In all financial years the wage expenditure has maintained $60 \%$ ratio, but in the year 2014-15 was not maintained 60 percent ratio of wage expenditure which means, most of the fund utilization and wage expenditure was used in agricultural lean season in Karnataka.

Figure No.2 Seasonal Wise Utilization of Fund and Expenditure on wage under MGNREGS in Karnataka (\%)

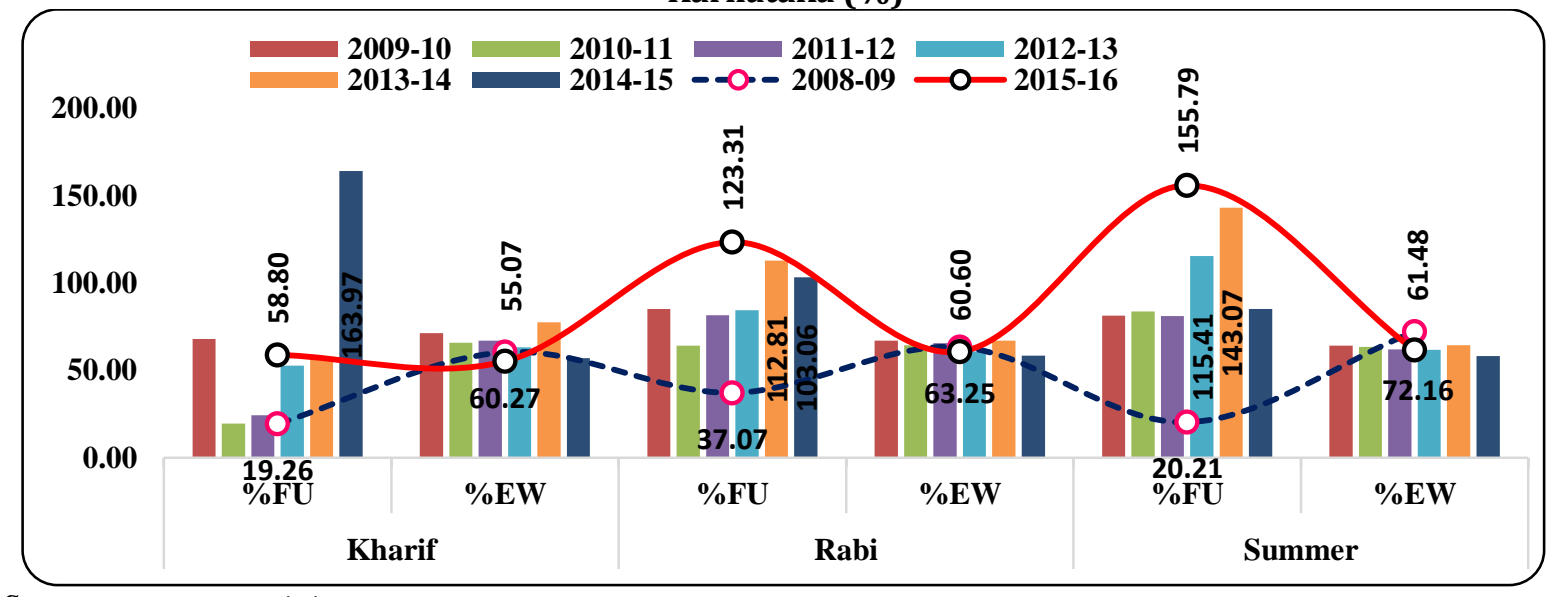

Source: www.mgnrega.nic.in.

Note: FU (Percentage of Fund Utilization) and EW (Percentage of Expenditure on Wage)

\subsection{To Assess the Seasonal Wise performance of Employment Generation under MGNREGS in Karnataka}

In this section the study discussed about the seasonal wise employment generation among social groups. Which is includes share of social groups by Demanded and Provided employment and Persondays, share of women employment, Average Persondays per households, Average percentage of households completed 100 days and finally the study intended to Comparison with Monthly Average Rainfall and Persondays generated under MGNREGA in Karnataka.

\subsubsection{Seasonal wise Percentage of Provided Employment and Percentage of Demand Gap under MGNREGS in Karnataka (2008-09 to 2016-17)}

The below table no.1 indicates that the Percentage of Provided Employment and Percentage of Demand Gap in Karnataka during the period 200809 to 2016-17. During the period 2008-09 to 2012-13 has significantly increased for provided employment and in the same period the demand gap was continuously decreased in during Kharif and Rabi season, but in Summer season there was slightly high demand gap, as compared to the total average provided and demand gap in Karnataka. In the period 2013-14 to 2015-16 the provided employment has significantly decreased in terms of the demand gap also significantly increased in during the Kharif and Rabi season but Rabi and summer season slightly variation as compared to the state average. In the year 2008-09 and 2016-17 as compared to the Summer and Rabi seasons are above the total state average percentage of provided employment. But least percent (85.3 in 2008-09, 73.21 in 2016-17) was in Kharif season, and in the same period the percentage of demand gap was highest (14.71 in 2008-09, 26.65 in 2016-17) percent during Kharif Season as compared to the total state average. Whereas least percent in Summer and Rabi season finally, the seasonal inequality in provided employment and demand gap was highest in Kharif 
and Rabi season with coefficient of variation of 33.78 percent. Whereas coefficient of variation is less in summer season it is evidently on an average 83 percent of workers are benefited from employment during the summer and Rabi season. the MGNREG scheme has positive impact on agricultural lean providing the employment opportunities for rural poor in India and Karnataka.

Table No.1 Seasonal wise Percentage of Provided Employment and Percentage of Demanded Gap under MGNREGS in Karnataka (\%)

\begin{tabular}{ccccccccc}
\hline \multirow{2}{*}{ Years } & \multicolumn{2}{c}{ Kharif } & \multicolumn{2}{c}{ Rabi } & \multicolumn{2}{c}{ Summer } & \multicolumn{2}{c}{ Total } \\
\cline { 2 - 9 } & HPE & DG & HPE & DG & HPE & DG & HPE & DG \\
\hline $\mathbf{2 0 0 8 - 0 9}$ & 85.29 & 14.71 & 95.49 & 4.51 & 98.49 & 1.51 & 93.9 & 6.1 \\
$\mathbf{2 0 0 9 - 1 0}$ & 97.43 & 2.57 & 97.36 & 2.64 & 97.23 & 2.77 & 97.33 & 2.67 \\
$\mathbf{2 0 1 0 - 1 1}$ & 96.18 & 3.82 & 97.49 & 2.51 & 94.34 & 5.66 & 95.69 & 4.31 \\
$\mathbf{2 0 1 1 - 1 2}$ & 98.17 & 1.83 & 99.19 & 0.81 & 99.36 & 0.64 & 99.12 & 0.88 \\
$\mathbf{2 0 1 2 - 1 3}$ & 99.5 & 0.5 & 99.68 & 0.32 & 94.31 & 5.69 & 97.45 & 2.55 \\
$\mathbf{2 0 1 3 - 1 4}$ & 54.04 & 45.96 & 62.63 & 37.37 & 64.25 & 35.75 & 62.43 & 37.57 \\
$\mathbf{2 0 1 4 - 1 5}$ & 48.04 & 51.96 & 60.63 & 39.37 & 58.14 & 41.86 & 56.28 & 43.72 \\
$\mathbf{2 0 1 5 - 1 6}$ & 31.36 & 68.64 & 57.5 & 42.5 & 65.75 & 34.25 & 55.68 & 44.32 \\
$\mathbf{2 0 1 6 - 1 7}$ & 73.21 & 26.79 & 75.85 & 24.15 & 76.03 & 23.97 & 75.07 & 24.93 \\
\hline Stdev & 25.65 & 25.65 & 18.47 & 18.47 & 16.89 & 16.89 & 18.97 & 18.97 \\
\hline Mean & 75.91 & 24.09 & 82.87 & 17.13 & 83.1 & 16.9 & 81.44 & 18.56 \\
\hline CV & $\mathbf{3 3 . 7 8}$ & $\mathbf{1 0 6 . 4 8}$ & $\mathbf{2 2 . 2 9}$ & $\mathbf{1 0 7 . 8 1}$ & $\mathbf{2 0 . 3 3}$ & $\mathbf{9 9 . 9 5}$ & $\mathbf{2 3 . 2 9}$ & $\mathbf{1 0 2 . 2}$ \\
\hline Source:
\end{tabular}

Source: $w w w . m g n r e g a . n i c . i n$

Note: HPE (Percentage of No. of households provided employment) and DG (Percentage of Demand Gap).

5.2.2 Seasonal wise Persondays generated among Social groups under MGNREGS in Karnataka

The below table no.2 reveals that the seasonal wise Persondays generated by social groups in MGNREG scheme in Karnataka during 2008-09 to 2016-17. In all financial year the SCs (42.77 percent in Rabi and 44.94 percent in Summer) and STs (12.22 percent in Kharif, 44.40 percent in Rabi and 43.38 percent in Summer season) Persondays has generated in Rabi and Summer season which is shows the overall year average Persondays generated. But in all season the Others (OBC) generated Persondays has been continuously decreased as compared to the state average of Persondays generated. But the least percentage of Persondays has generated in during Kharif season. in kharif season the coefficient of variation was highest percent in all social groups as compared to the other seasons, but in Rabi season has least variation in persondays generated.

Table No.2 Seasonal wise Persondays generated among Social groups under MGNREGS in Karnataka (\%)

\begin{tabular}{ccccccccccccc}
\hline \multirow{2}{*}{ year } & \multicolumn{3}{c}{ Kharif } & \multicolumn{4}{c}{ Rabi } & \multicolumn{3}{c}{ Summer } & \multicolumn{3}{c}{ Total } \\
\cline { 2 - 12 } & SCs & STs & Others & SCs & STs & Others & SCs & STs & 0thers & SCs & STs & Others \\
\hline $\mathbf{2 0 0 8 - 0 9}$ & 18.42 & 15.42 & 15.03 & 44.81 & 55.47 & 51.95 & 36.77 & 29.11 & 33.02 & 24.28 & 15.31 & 60.41 \\
$\mathbf{2 0 0 9 - 1 0}$ & 16.21 & 15.74 & 13.58 & 47.93 & 48.07 & 47.46 & 35.87 & 36.19 & 38.96 & 17.96 & 9.19 & 72.85 \\
$\mathbf{2 0 1 0 - 1 1}$ & 7.71 & 8.51 & 7.09 & 34.51 & 35.62 & 33.69 & 57.78 & 55.87 & 59.22 & 16.47 & 10.02 & 73.52 \\
$\mathbf{2 0 1 1 - 1 2}$ & 9.88 & 9.78 & 10.33 & 38.09 & 38.2 & 38.19 & 52.04 & 52.02 & 51.48 & 15.58 & 8.23 & 76.19 \\
$\mathbf{2 0 1 2 - 1 3}$ & 9.83 & 10.38 & 9.32 & 38.22 & 38.82 & 38.31 & 51.95 & 50.81 & 52.37 & 16.96 & 9.28 & 73.75 \\
$\mathbf{2 0 1 3 - 1 4}$ & 6.32 & 6.96 & 6.16 & 43.65 & 44.71 & 42.56 & 50.03 & 48.32 & 51.29 & 16.11 & 8.39 & 75.5 \\
$\mathbf{2 0 1 4 - 1 5}$ & 21.7 & 22.22 & 22.32 & 45.63 & 45.32 & 45.57 & 32.66 & 32.46 & 32.11 & 15.63 & 8.14 & 76.23 \\
$\mathbf{2 0 1 5 - 1 6}$ & 8.31 & 8.77 & 7.71 & 49.29 & 48.94 & 48.9 & 42.39 & 42.29 & 43.39 & 16.54 & 9.18 & 74.29 \\
\hline Stdev & $\mathbf{5 . 6 8}$ & $\mathbf{5 . 1 4}$ & $\mathbf{5 . 3 8}$ & $\mathbf{5 . 2 5}$ & $\mathbf{6 . 5 9}$ & $\mathbf{6 . 2 4}$ & $\mathbf{9 . 2 3}$ & $\mathbf{9 . 9}$ & $\mathbf{9 . 9}$ & $\mathbf{2 . 8 7}$ & $\mathbf{2 . 3 5}$ & $\mathbf{5 . 1 8}$ \\
\hline Mean & $\mathbf{1 2 . 3}$ & $\mathbf{1 2 . 2 2}$ & $\mathbf{1 1 . 4 4}$ & $\mathbf{4 2 . 7 7}$ & $\mathbf{4 4 . 4}$ & $\mathbf{4 3 . 3 3}$ & $\mathbf{4 4 . 9 4}$ & $\mathbf{4 3 . 3 8}$ & $\mathbf{4 5 . 2 3}$ & $\mathbf{1 7 . 4 4}$ & $\mathbf{9 . 7 2}$ & $\mathbf{7 2 . 8 4}$ \\
\hline CV & $\mathbf{4 6 . 2 1}$ & $\mathbf{4 2 . 0 9}$ & $\mathbf{4 6 . 9 9}$ & $\mathbf{1 2 . 2 8}$ & $\mathbf{1 4 . 8 5}$ & $\mathbf{1 4 . 4}$ & $\mathbf{2 0 . 5 5}$ & $\mathbf{2 2 . 8 2}$ & $\mathbf{2 1 . 8 9}$ & $\mathbf{1 6 . 4 5}$ & $\mathbf{2 4 . 1 5}$ & $\mathbf{7 . 1 1}$ \\
\hline Source: www.mgnrega.nic.in & & & & & & & & &
\end{tabular}




\subsubsection{Seasonal Wise Women Persondays Generated under MGNREGS in Karnataka}

Women participation is very important aspect in the economy particularly in rural India. women are traditionally discriminated against and excluded from political and family related decision making, in this concern the government has taken many programmes and opportunities for women. The mandatory 33 percent of work should be given to women under MGNREGS. The below figure no.3 illustrated that the Seasonal wise women Persondays generated in MGNREGS during the period of 200809 to 2015-16. As compared to the all financial years, on an average of women generated Persondays was highest 44.50 percent in summer season followed by 43.64 percent in Rabi, but in Kharif season was least 11.85 percent. the women persondays generated has been increased from 31.01 percent in 2008-09 to 59.46 percent in $2010-11$. Then it has continuously decreased form 51.77 percent in 2011-12 to 32.30 percent in 2014-15 it was during summer season, in Rabi season the women generated Persondays has been continuously decreased from 52.75 percent in 2008-09 to 33.32 percent in 2010-11 and then it has been continuously increased from 38 percent in 2011-12 to 48.84 percent in 2015-16. But in Kharif season least share of women persondays was observed in all the period.

Figure No.3 Seasonal Wise Women Persondays Generated Under MGNREGS in Karnataka (2008-09 to 2015-16).

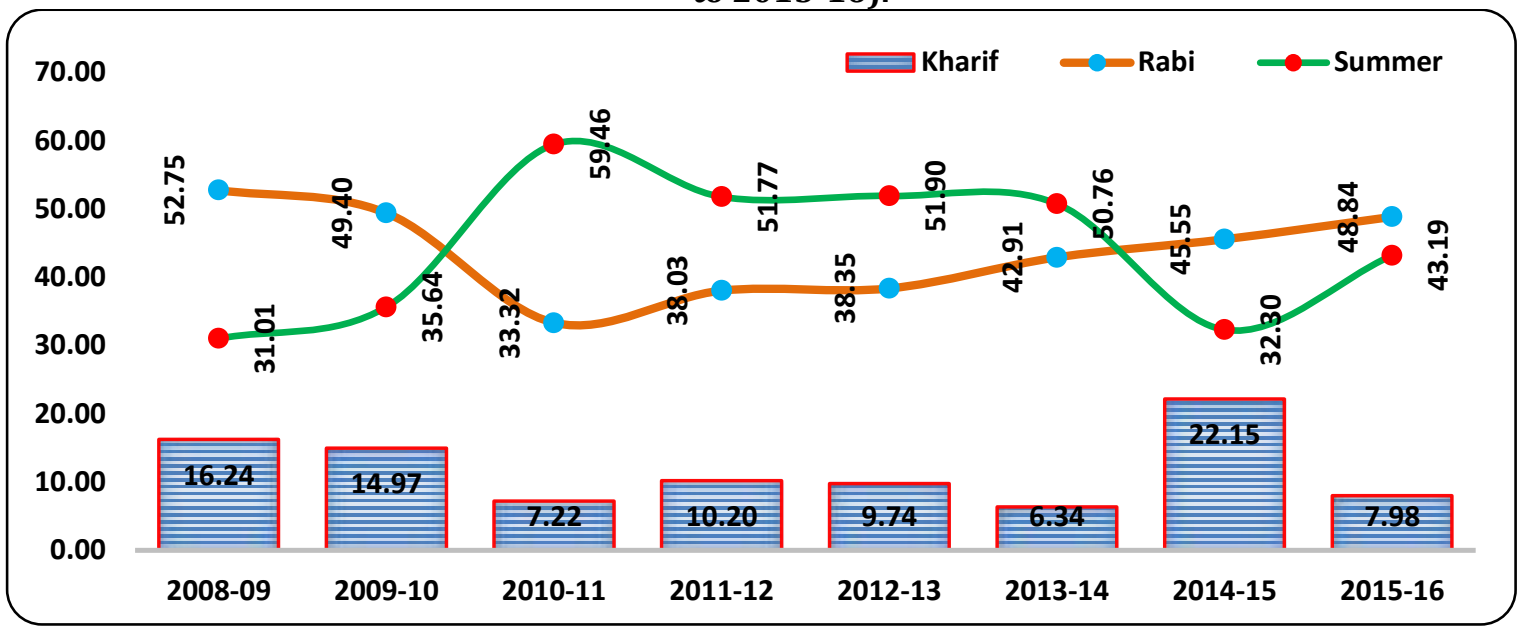

Source: $w w w . m g n r e g a . n i c . i n$

\subsubsection{Seasonal variation of Average} Persondays per Households under MGNREGS in Karnataka

The below figure-4 indicates that the seasonal variation of average persondays per household under MGNREGS in Karnataka. Similarly, above 30 days in Rabi season was highest in seven financial years, but except 2012-13. Followed by Rabi season has four years but except 2011-12 and 2012-13. In Kharif season there are two years has above the 30 days except 2008-09, 2010-11, 2011-12, 2012-13, 2013-14 and 2015-16. The MGNREGS works should be focus on Summer and Rabi season.

Figure No. 4 Seasonal variation of Average Persondays per Households under MGNREGS in Karnataka (2008-09 to 2015-16)

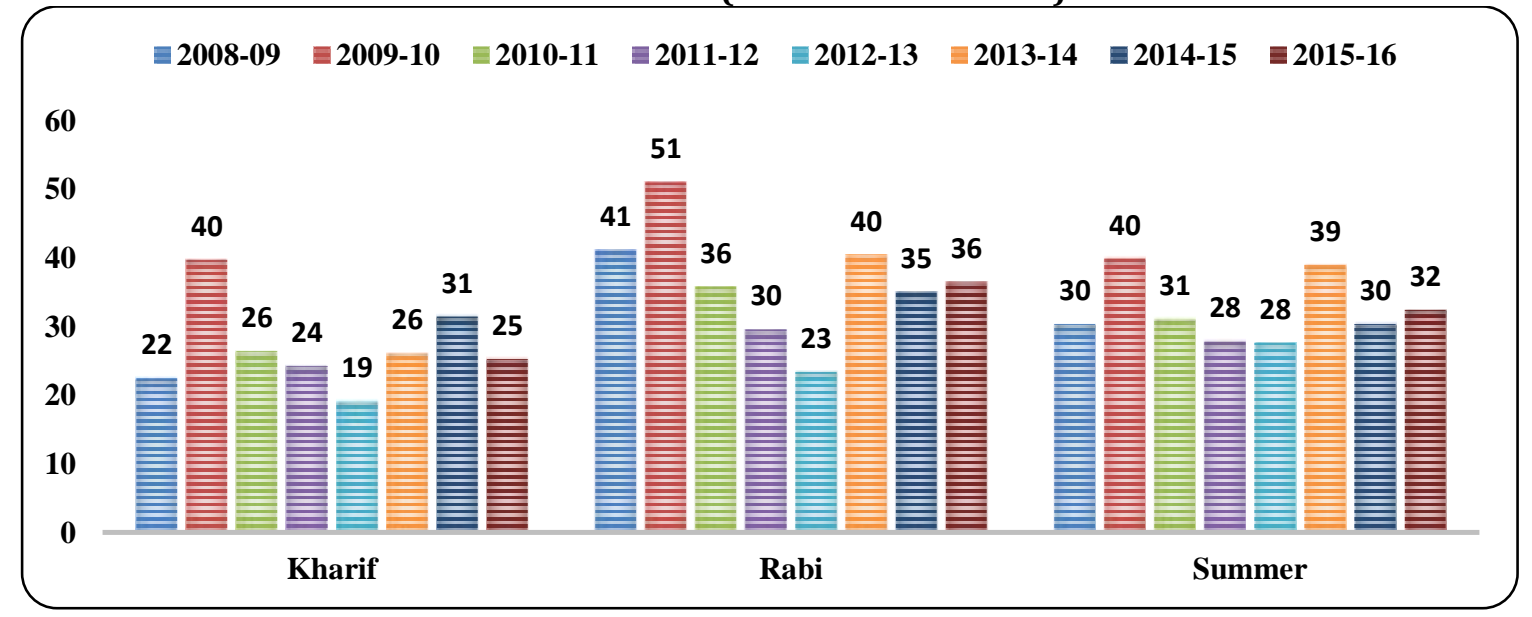

Source: www.mgnrega.nic.in 


\subsubsection{Season wise Average percentage of No. of Households Completed 100 Days under MGNREGS in Karnataka 2008-16.}

The below figure-5 shows that the seasonal wise average percentage of No. of household completed 100 days under MGNREGS in Karnataka. Similar in all year's during summer and Rabi season has highest proportion of hundred days wok done, but least proportion in Kharif season. in the year 2009-10 the no. of household completed hundred days has highest proportion in all season. During summer season the completion of 100 day's work has been increased from 2.57 percent in 2008-09 to 7.17 percent in 2015-16. In the same period during Rabi season the share of hundred days wok completion has increased from 1.93 percent in 2008-09 to 3.36 percent in 2015-16, but least proportion in during kharif season. It is clearly indicating that the most of workers have completed hundred days in Summer and Rabi season.

Figure No.5 Season wise Average percentage of No. of Households Completed 100 Days under MGNREGS in Karnataka.

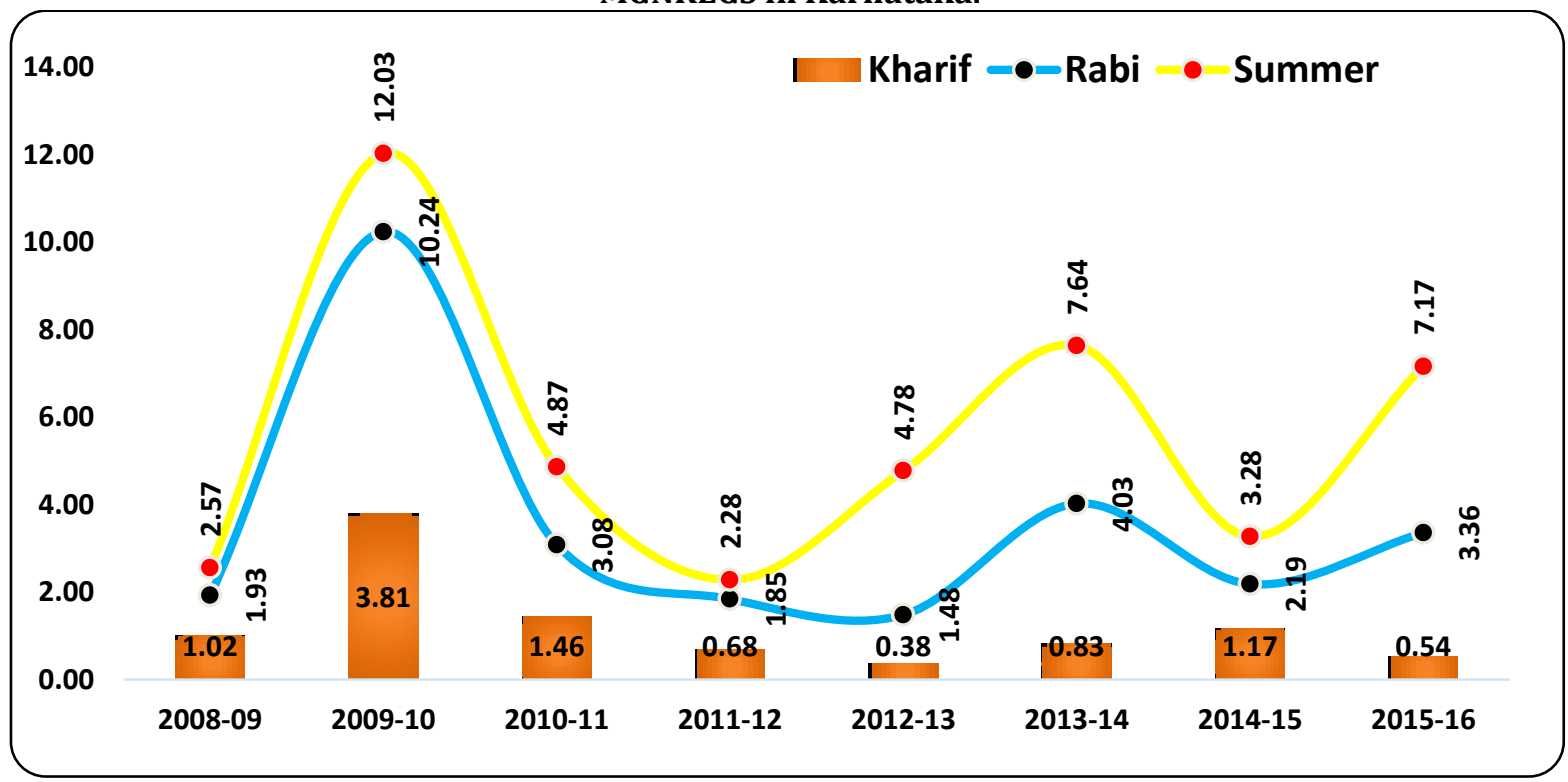

Source: www.mgnrega.nic.in

\subsubsection{Month Wise average Rainfall and Generated Persondays under MGNREGS in Karnataka}

Rain is main source for the economic development, as well as human wants also. low rainfall is very unsafe factor. So, its affected on low agriculture production, low employment opportunity, lack food availability and so negative impact on livelihood. in this context the scheme provides 100days and to extra 50days in drought affected areas, land development works for small and marginal farmers and creation of sustainable asset in rural Karnataka and India. The workers have got an employment opportunity. most important factor to improve income and livelihood security for rural poor. In this below figure No-6 shows that drought affected taluks in Karnataka during 2001 to 2018 . The No. of drought affected taluks has been continuously increased from 33 taluks in 2001 to 156 taluks in 2018. In the year 2017 has 162 taluks was drought affected areas in Karnataka. This indicates that in these Eighteen years, but except three years (2005, $2007 \& 2010$ ) have no drought or droughty situation. In rest of 15 years 2003 and 2017 was a severe drought year since 162 taluks out of 176 taluks (92\%) were reeling under drought. In 2002, 2012 \& 2018 out of 176 taluks 159 taluks $(90 \%), 157$ taluks (89\%) and 156 taluks (89\%) were affected by drought. Among these 15 years in $2001 \& 2014$ the drought was less intense (18-20\%) and only 33 to 35 taluks were affected while in all the 13 years the drought was wide spread $(>50 \%)$ and severe to very severe in the state. In this regard performance of MGNREGS in drought affected areas in Karnatak. 
Figure 6: No. of Drought Affected Taluks in Karnataka:2001 to 2018

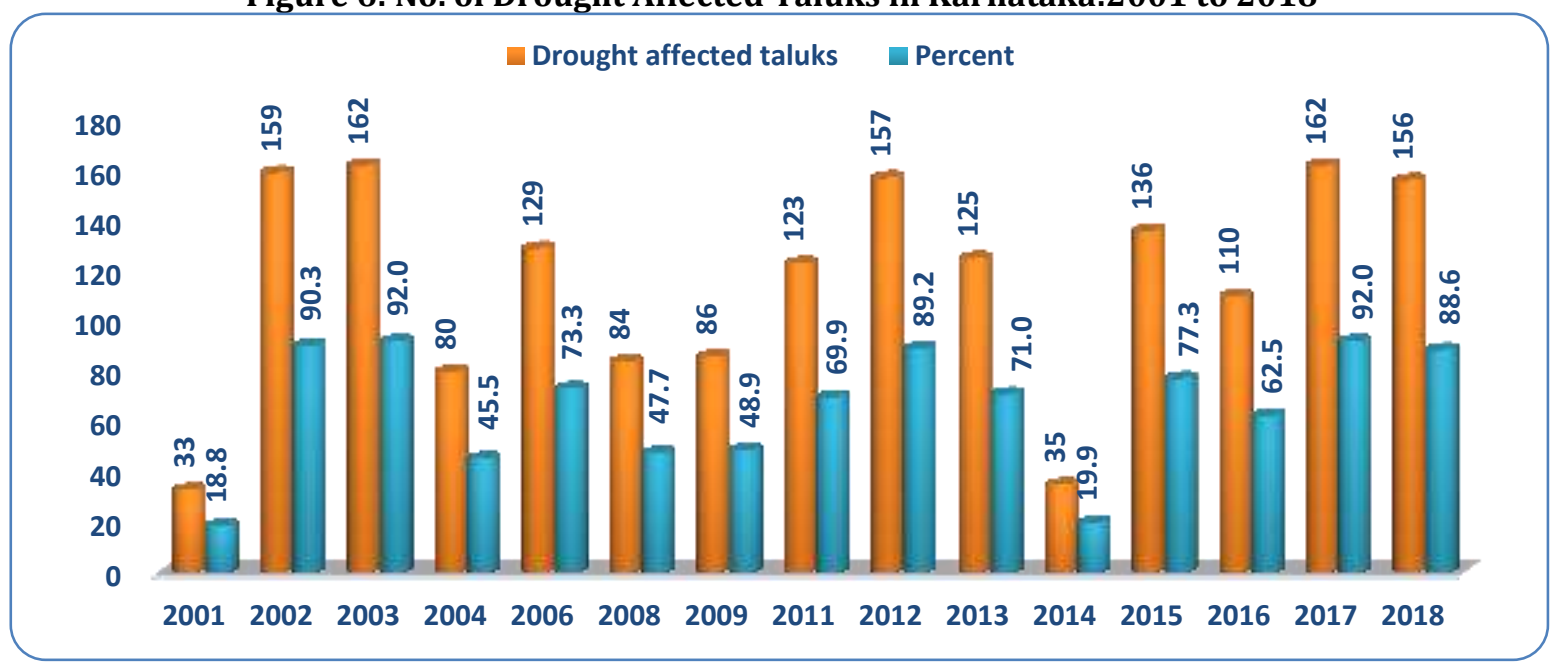

Source: KSNDMC reports $2017 \&$ http://www.newindianexpress.com/states/karnataka/2019.

The below figure-7 illustrated that monthly rainfall and persondays generated under MGNREGS in Karnataka during 2013 to 2017 . The study found that the highest proportion of persondays generated (531lakhs), average rain fall is lit bit very high $(101 \mathrm{~mm})$ and highest (92 percent) share of drought affected taluks were found in the year 2017. similarly, in 2016 has high generated persondays 453 lakhs, but average rain fall is very low $(83 \mathrm{~mm})$ and the drought was 62.5 percent, In the year 2013 has persondays generated around 215 lakhs average rain fall around $(177 \mathrm{~mm})$ and drought was 71 percent and in 2015 Mandays generated has 199 lakhs, average rain fall was around $(97 \mathrm{~mm})$, but drought was 77.3 percent. Among these five years, in 2014 the drought was very less (19.9 percent), but on an average generated Mandays was high (331) proportion and average rainfall very high.

The study found that the MGNREG scheme has positive response in cold weather period and north east monsoon period. The study mainly efforts on rainy season it means south west monsoon period the proportion of average rainfall was highest (486mm in July 2013), but it is continuously declined to $244 \mathrm{~mm}$ in July 2017 . But not more rainfall in other remaining months. in this regard the act has given a right to work 150days in drought affected areas. the beneficiaries should to use these extra days work and generate income and sustain their life style.

Figure No.7 Month Wise average Rainfall and Generated Persondays under MGNREGS in Karnataka (2013-14 to 2016-17).

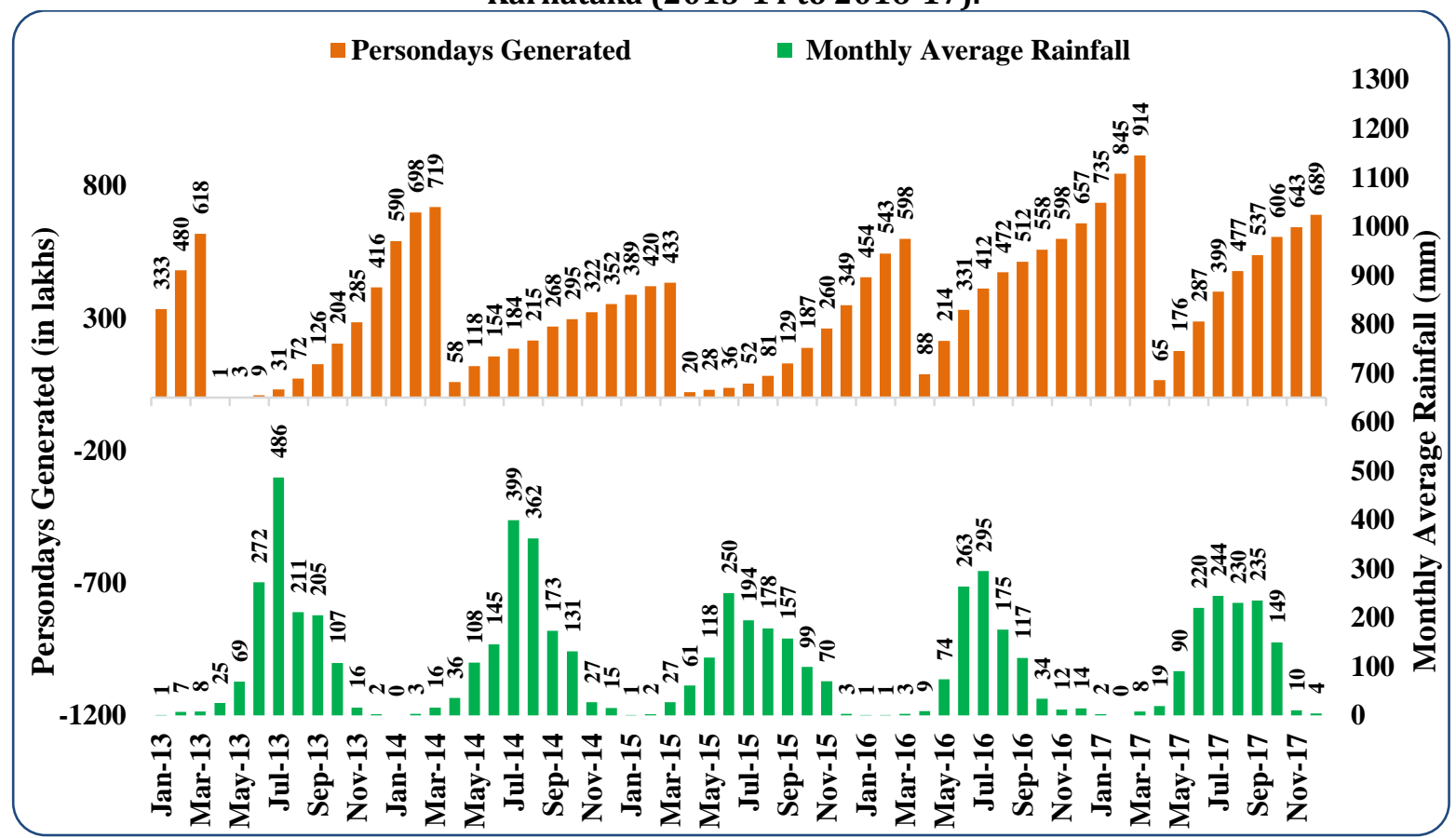

Source: www.mgnrega.nic.in. and http://des.kar.nic.in/acrs_rf_reports. 


\section{FINDINGS AND SUGGESTIONS}

\section{Findings}

$\checkmark \quad$ It was evident that there has been proper utilization of fund was found in 2018-19 with 97.75 percent in Karnataka. But worst performance in utilizing the fund has seen in 2010-11 which was accounted for 62.93 percent even though the availability of fund was higher.

$\checkmark$ The amount of expenditure incurred is highest in the year 2018-19, but the percentage of fund utilized is highest over these thirteen years.

$\checkmark \quad$ In all financial years the wage expenditure has maintained $60 \%$ ratio, but in the year 2014-15 was not maintained 60 percent ratio of wage expenditure which means, most of the fund utilization and wage expenditure was used in agricultural lean season in Karnataka.

$\checkmark$ Whereas coefficient of variation is less in summer season it is evidently on an average 83 percent of workers are benefited from employment during the summer and Rabi season.

\section{Suggestions}

- Proper season wise planning and timely work distribution for who have demanded for work.

- The study has suggested to aware about MGNREGA and extra 50days work in drought affected areas.

- To give more importance for agriculture works and allied works in grass root level.

\section{CONCLUSION}

The MGNREGS is a world largest public wage employment programme. Most of the participant are poor and socially vulnerable section of the society. This programme has positive impact on socio economic condition of beneficiaries and also sustain their livelihood. But facing mass poverty in rural areas, especially social groups and also agriculture suffering from vulnerability of agriculture production and environmental risks. Therefore, the study suggests that the MGNREGS works should be

\section{REFERENCES}

1. Akhilesh $K$ Sharma, M. R. (2016). Macroeconomic Impact of Social Protection Programmes in India. Economic \& Political Weekly, Vol. LI, No.34.

2. Ministry of Rural Development (2012), MGNREGS Sameeksha: An Anthology of Research Studies on the Mahatma Gandhi National Rural Employment Guarantee Act, 2005, Government of India.

3. N. Pani and C.Iyer. (2011). 'Evaluation of the Impact of Processes in the Mahatma Gandhi $\checkmark \quad$ As compared to the all-financial years, on an average of women generated Persondays was highest 44.50 percent in summer season followed by 43.64 percent in Rabi, but in Kharif season was least 11.85 percent.

$\checkmark$ Similar in all year's during summer and Rabi season have highest proportion of hundred days wok done, but least proportion in Kharif season.

$\checkmark \quad$ The study found that the highest proportion of persondays generated (531lakhs), average rain fall is lit bit very high $(101 \mathrm{~mm})$ and highest (92 percent) share of drought affected taluks were found in the year 2017.

$\checkmark$ Among these five years, in 2014 the drought was very less (19.9 percent), but on an average generated Mandays was high (331) proportion and average rainfall very high.

$\checkmark$ The study mainly efforts on rainy season it means south west monsoon period the proportion of average rainfall was highest (486mm in July 2013), but it is continuously declined to $244 \mathrm{~mm}$ in July 2017. But not more rainfall in other remaining months.

- Adequate steps towards timely work completion should be ensured.

- To ensure more participation of women in MGNREGS, in terms of proper worksite facilities such as creches, drinking water, shade etc. and also encourage participation of women groups, including self-help groups capturing of demand, planning, implementation, monitoring and maintenance of works.

enhanced in agriculture offseason, to focus on natural resources management works related to agriculture works and drought affected areas in rural Karnataka and India. Proper season wise planning and timely work distribution for who have demanded for work and to focus on land development works for small and marginal farmers in rural areas. The MGNREGA programme is one of the tools for achieving towards sustainable development goals in future.

National Rual Employment Guarantee Scheme in Karnataka. Bangalore: National Institute of Advanced Studies (NIAS).

4. P.S. Srikantha Murthy and Indumati, P. S. (2011). Economic Analysis of MGNREGA in the Drought-prone States of Karnataka, Rajasthan and Irrigation-dominated State of Andhra Pradesh. Agricultural Economics Research Review, 531-536.

5. Prasanna V. Salian and D.S Leelavathi. (2014). Implementation of MGNREGA in Karnataka: Issues and Challenges. Journal of Rural Development, Vol.33,No.3. 
6. S.M.Vanitha and P.S.Srikantha Murthy. (2011). An Economic Analysis of MGNREG Programme in Mysore District of Karnataka. Agriclutural Economics Research Review, 415-422.

7. KSNDMC (2017), Drought Vulnerability Assessment in Karnataka (A Composite Index: Using Climatic, Soil, Crop Cover and Livelihood Components), Karnataka State Natural Disaster Monitoring Centre, Bengaluru, $114 p$.

8. www.mgnrega.nic.in

9. http://des.kar.nic.in/acrs_rf_report.

10. http://www.newindianexpress.com/states/karnata ka/2019/mar/01/15-drought-years-in-state-since2000-byregowda-1945203.html 